\title{
Propylthiouracil-induced hypothyroidism protects ionizing radiation-induced multiple organ damage in rats
}

\author{
G Şener, L Kabasakal, B M Atasoy ${ }^{1}$, C Erzik ${ }^{2}$, A Velioğlu-Öğünçç, \\ Ş Çetinel ${ }^{4}$, G Contuk ${ }^{4}$, N Gedik ${ }^{5}$ and B Ç Yeğen ${ }^{6}$
}

\author{
Department of Pharmacology, School of Pharmacy, Marmara University, Istanbul, Turkey \\ ${ }^{1}$ Department of Radiation Oncology, School of Medicine, Marmara University, Istanbul, Turkey \\ ${ }^{2}$ Department of Medical Biology, School of Medicine, Marmara University, Istanbul, Turkey \\ ${ }^{3}$ Vocational School of Health Related Professions, Marmara University, Istanbul, Turkey \\ ${ }^{4}$ Department of Histology-Embryology, School of Medicine, Marmara University, Istanbul, Turkey \\ ${ }^{5}$ Division of Biochemistry, Kasımpasa Military Hospital, Istanbul, Turkey \\ ${ }^{6}$ Department of Physiology, School of Medicine, Marmara University, Haydarpaşa, Istanbul 34668, Turkey \\ (Requests for offprints should be addressed to B Ç Yeğen; Email: byegen@marmara.edu.tr)
}

\begin{abstract}
The objective of this study was to examine the potential radioprotective properties of propylthiouracil (PTU)induced hypothyroidism against oxidative organ damage induced by irradiation. Sprague-Dawley rats were pretreated with saline or PTU (10 mg/kg i.p.) for 15 days, and were then exposed to whole-body irradiation (800 cGy). A group of rats were decapitated at $6 \mathrm{~h}$ after exposure to irradiation, while another group was followed for $72 \mathrm{~h}$ after irradiation, during which saline or PTU injections were repeated once daily. Lung, liver, kidney and ileum samples were obtained for the determination of malondialdehyde (MDA; an index of lipid peroxidation) and glutathione (GSH, an antioxidant) levels, myeloperoxidase activity (MPO; an index of tissue neutrophil accumulation) and collagen contents, while oxidantinduced DNA fragmentation was evaluated in the ileal tissues. All tissues were also examined microscopically and assayed for the production of reactive oxidants using
\end{abstract}

chemiluminescence (CL). Lactate dehydrogenase (LDH), an indicator of tissue damage, and tumour necrosis factor- $\alpha$ (TNF $\alpha)$ were assayed in serum samples. Irradiation caused a significant decrease in GSH level, which was accompanied by significant increases in MDA levels, MPO activity, CL levels and collagen content of the tissues studied $(P<0 \cdot 05-0 \cdot 001)$. Similarly, serum $\mathrm{TNF} \alpha$ and LDH were elevated in the irradiated rats as compared with the control group. On the other hand, PTU treatment reversed all these biochemical indices, as well as histopathological alterations induced by irradiation. Our results suggested that PTU-induced hypothyroidism reduces oxidative damage in the lung, hepatic, renal and ileal tissues probably due to hypometabolism, which is associated with decreased production of reactive oxygen metabolites and enhancement of antioxidant mechanisms.

Journal of Endocrinology (2006) 189, 257-269

\section{Introduction}

Oxidative stress occurs due to excessive free radical production and/or low antioxidant defence, and results in chemical alterations of bio-molecules causing structural and functional modifications (Edwards et al. 1984, Robbins \& Zhao 2004). The generation of the reactive oxygen metabolites (ROMs) plays an important role in the pathogenesis of irradiation-induced tissue injury. An extensive literature implicates cellular DNA as the primary target for the biological and lethal effects of ionizing radiation. Additionally, DNA, lipids and proteins are also attacked by free radicals induced by ionizing radiation (Daly et al. 1999, Agrawal et al. 2001). Thus, drugs that scavenge or inhibit the formation of ROMs may have relevance to cancer patients by ameliorating the damage to normal tissues exposed to ionizing irradiation therapy.

Thyroid hormones are among the most important humoral factors involved in setting the basal metabolic rate (Guerrero et al. 1999). It is well known that thyroid hormones increase mitochondrial respiration through changes in the number and activity of mitochondrial respiratory chain components, providing a considerable impact on oxidative stress (Roodyn et al. 1965, Karbownik \& Lewinski 2003). Accordingly, it was reported that the thyroid state might alter the changes in oxidant and antioxidant systems (Brzezinska-Slebodzinska 2001). High concentrations of thyroid hormones and thyrotoxicosis can facilitate the metabolism of oxygen in 
Table 1 Serum AST, ALT, BUN, creatinine and LDH levels in control and saline- or PTU-treated groups decapitated at 6 or $72 \mathrm{~h}$ after irradiation (IR)

\begin{tabular}{|c|c|c|c|c|c|c|}
\hline & \multirow{2}{*}{\multicolumn{2}{|c|}{ Control groups }} & \multicolumn{4}{|l|}{ IR groups } \\
\hline & & & \multicolumn{2}{|l|}{$6 \mathrm{~h}$} & \multicolumn{2}{|l|}{$72 \mathrm{~h}$} \\
\hline & Saline & PTU & Saline & PTU & Saline & PTU \\
\hline $\operatorname{ALT}(\mathrm{U} / \mathrm{I})$ & $104 \pm 6 \cdot 7$ & $99 \pm 7 \cdot 1$ & $153 \pm 8 \cdot 3^{*}$ & $110 \pm 21 \cdot 1$ & $204 \pm 20 \cdot 0^{* *}$ & $123 \pm 11 \cdot 6^{+}$ \\
\hline AST $(\mathrm{U} / \mathrm{I})$ & $271 \pm 34$ & $267 \pm 22$ & $330 \pm 29$ & $255 \pm 25$ & $376 \pm 52^{*}$ & $246 \pm 14^{+}$ \\
\hline BUN (U/I) & $35 \cdot 6 \pm 1 \cdot 4$ & $33 \cdot 0 \pm 1 \cdot 1$ & $36 \cdot 1 \pm 3 \cdot 3$ & $35 \cdot 4 \pm 2 \cdot 5$ & $66 \cdot 8 \pm 6 \cdot 4^{* * *}$ & $44 \cdot 0 \pm 4 \cdot 5^{+++}$ \\
\hline
\end{tabular}

Each group consists of six rats. ${ }^{*} P<0 \cdot 05,{ }^{* *} P<0 \cdot 01,{ }^{* * *} P<0 \cdot 001$ compared with control group; ${ }^{+} P<0 \cdot 05,{ }^{+++} P<0 \cdot 001$ compared with saline-treated IR group.

aerobic conditions, stimulate free radical generation and aggravate oxidant-mediated tissue injury (Asayama \& Kato 1990, Venditti et al. 1997). On the other hand, metabolic depression brought about by hypothyroidism has been associated with decreased oxidant production and protection against tissue lipid peroxidation (Swaroop \& Ramasarma 1985, Paller 1986).

Based on these reports, this study was designed to determine the possible protective effect of hypothyroidism against irradiation-induced oxidative damage of the gastrointestinal tissues in rats by evaluating the extent of tissue injury through biochemical and histological analyses.

\section{Materials and Methods}

Experimental design

All experimental protocols were approved by the Marmara University School of Medicine Animal Care and
Use Committee. Male Sprague-Dawley rats (200-250 g) were kept at a constant temperature $\left(22 \pm 1{ }^{\circ} \mathrm{C}\right)$ under $12 \mathrm{~h}$ light:12 h darkness cycles.

A total of 32 animals were exposed to irradiation performed with a LINAC (Saturne 42, General Electrics, France) producing $6 \mathrm{MV}$ photons at a focus $100 \mathrm{~cm}$ distant from the skin. Under ketamine anaesthesia $(100 \mathrm{mg} / \mathrm{kg}$ i.p.), each rat received a single whole-body X-ray irradiation of $800 \mathrm{cGy}$. Animals were returned to their home cages following irradiation. Control rats $(n=6)$ received no irradiation or treatment.

Rats were pretreated daily with either 6-n-propyl-2thiouracil (PTU; 10 mg/kg i.p.; Sigma Chemical Co., St Louis, MO, USA) or saline $(1 \mathrm{ml} / \mathrm{kg})$ for 15 days before irradiation. In the rats followed for $72 \mathrm{~h}$ after irradiation, saline or PTU injections were repeated once daily. Rats were decapitated at $6 \mathrm{~h}$ and $72 \mathrm{~h}$ after exposure to irradiation, trunk blood was collected and the serum was separated to measure the aspartate aminotransferase (AST) and alanine aminotransferase (ALT) levels and creatinine

Table 2 Luminol and lucigenin CL levels in the lung, liver, kidney and ileal tissues of control and saline- or PTU-treated groups decapitated at 6 or $72 \mathrm{~h}$ after irradiation (IR)

\begin{tabular}{|c|c|c|c|c|c|c|}
\hline & \multirow{2}{*}{\multicolumn{2}{|c|}{ Control groups }} & \multicolumn{4}{|l|}{ IR groups } \\
\hline & & & \multicolumn{2}{|l|}{$6 \mathrm{~h}$} & \multicolumn{2}{|l|}{$72 \mathrm{~h}$} \\
\hline & Saline & PTU & Saline & PTU & Saline & PTU \\
\hline \multicolumn{7}{|c|}{ Relative light units } \\
\hline \multicolumn{7}{|c|}{ Lung } \\
\hline Luminol & $11 \cdot 2 \pm 1 \cdot 9$ & $10 \cdot 1 \pm 1 \cdot 1$ & $26 \cdot 5 \pm 2 \cdot 2^{* * *}$ & $14 \cdot 9 \pm 0 \cdot 8^{+++}$ & $27 \cdot 8 \pm 1 \cdot 8^{* * *}$ & $15 \cdot 1 \pm 1 \cdot 5^{+++}$ \\
\hline Luminol & $11 \cdot 6 \pm 1 \cdot 4$ & $9 \cdot 4 \pm 1 \cdot 1$ & $31 \cdot 2 \pm 1 \cdot 8^{* * *}$ & $12 \cdot 5 \pm 2 \cdot 7^{+}$ & $29 \cdot 1 \pm 1 \cdot 1^{* * *}$ & $19 \cdot 3 \pm 2 \cdot 6^{++}$ \\
\hline Lucigenin & $12 \cdot 8 \pm 0 \cdot 7$ & $11 \cdot 4 \pm 1 \cdot 5$ & $30 \cdot 4 \pm 2 \cdot 9^{* *}$ & $20 \cdot 3 \pm 1 \cdot 1^{* *,++}$ & $28 \cdot 1 \pm 1 \cdot 6^{* * *}$ & $16 \cdot 2 \pm 0 \cdot 6^{+++}$ \\
\hline \multicolumn{7}{|l|}{ Kidney } \\
\hline Luminol & $14 \cdot 6 \pm 1 \cdot 9$ & $12 \cdot 7 \pm 2 \cdot 2$ & $42 \cdot 1 \pm 6 \cdot 3^{* * *}$ & $14 \cdot 0 \pm 2 \cdot 3^{+++}$ & $37 \cdot 1 \pm 4 \cdot 5^{* * *}$ & $16 \cdot 1 \pm 1 \cdot 4^{+++}$ \\
\hline Lucigenin & $9 \cdot 7 \pm 1 \cdot 4$ & $10 \cdot 8 \pm 1 \cdot 1$ & $23 \cdot 6 \pm 1 \cdot 2^{* * *}$ & $12 \cdot 6 \pm 1 \cdot 1^{+++}$ & $25 \cdot 1 \pm 1 \cdot 5^{* *}$ & $16 \cdot 9 \pm 1 \cdot 9^{* *+++}$ \\
\hline \multicolumn{7}{|l|}{ İleum } \\
\hline
\end{tabular}

Each group consists of six rats. ${ }^{*} P<0 \cdot 05,{ }^{* *} P<0 \cdot 01,{ }^{* * *} P<0 \cdot 001$ compared with control group; ${ }^{+} P<0 \cdot 05,{ }^{++} P<0 \cdot 01,{ }^{+++} P<0 \cdot 001$ compared with saline-treated IR group. 


\section{a)}

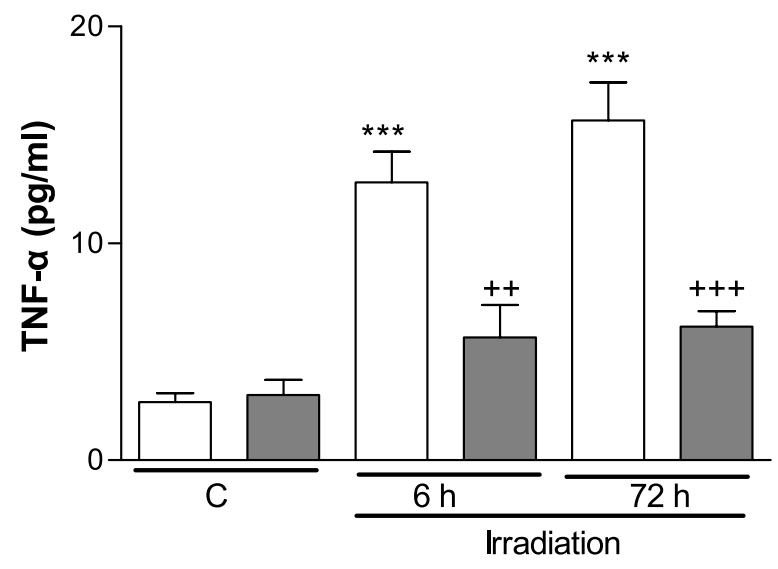

b)

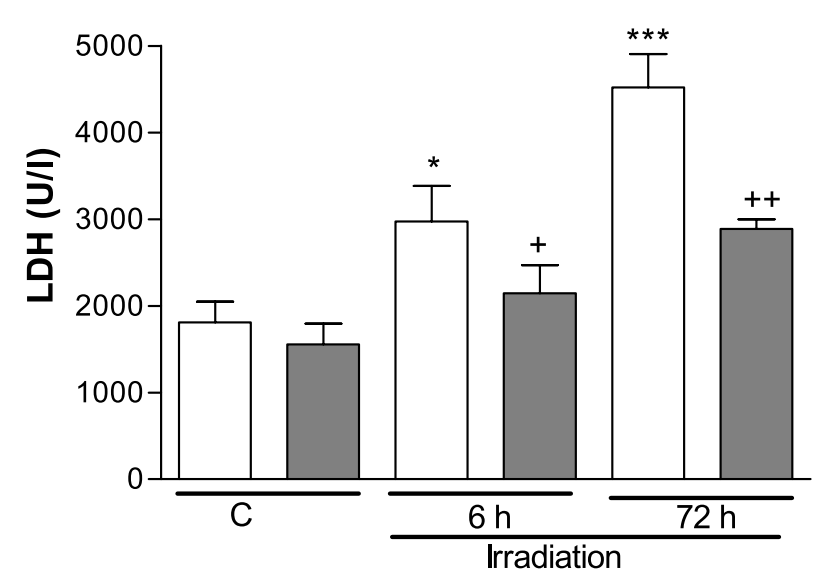

$\square$ Saline-treated

Figure 1 (a) TNF $\alpha$ and (b) LDH levels in serum samples of control and vehicle- or PTU-treated groups decapitated at 6 or $72 \mathrm{~h}$ after irradiation. Each group consists of six rats. ${ }^{*} P<0 \cdot 05,{ }^{*} P<0 \cdot 01$, ${ }^{* * *} P<0 \cdot 001$ compared with control (C) group; ${ }^{+} P<0 \cdot 05,{ }^{++} P<0 \cdot 01$, ${ }^{+++} P<0.001$ compared with saline-treated group.

and blood urea nitrogen (BUN) as indicators of liver and kidney functions respectively. Lactate dehydrogenase $(\mathrm{LDH})$ and tumour necrosis factor- $\alpha(\mathrm{TNF} \alpha)$ were also assayed in serum samples for the evaluation of generalized tissue damage. Tissue samples from the lung, liver, kidney and ileum were fixed in formaldehyde for histological analysis, while additional samples were stored at $-80^{\circ} \mathrm{C}$ for the determination of malondialdehyde (MDA) and glutathione (GSH) levels, myeloperoxidase (MPO) activity and collagen content. Formation of reactive oxygen species (ROS) in the tissue samples was monitored using the chemiluminescence $(\mathrm{CL})$ technique with luminol and lucigenin probes. Additional ileal samples were obtained for the determination of DNA fragmentation as an index of apoptosis.

\section{Blood assays}

BUN (Talke \& Schubert 1965), serum AST, ALT (Moss et al. 1987) and creatinine (Slot 1965) concentrations and LDH levels (Martinek 1972) were determined spectrophotometrically using an automated analyzer. TNF $\alpha$ was evaluated by an RIA-IRMA method. All samples were assayed in duplicate using a commercial kit (Biosource Europe S.A., Nivelles, Belgium). The activity of radioactive assays was measured by a $\gamma$ counter (LKB WALLAC 1270 RACK Gamma Counter, Turku, Finland). TNF $\alpha$ in the serum samples is expressed as $\mathrm{pg} / \mathrm{ml}$.

\section{$M D A$ and $G S H$ assays}

Tissue samples were homogenized with ice-cold $150 \mathrm{mM}$ $\mathrm{KCl}$ for the determination of MDA and GSH levels. The MDA levels were assayed for products of lipid peroxidation by monitoring thiobarbituric acid reactive substance formation as described previously (Beuge \& Aust 1978). Lipid peroxidation is expressed in terms of MDA equivalents using an extinction coefficient of $1.56 \times 10^{5} \mathrm{M} / \mathrm{cm}$ and results are expressed as nmol MDA/g tissue. GSH measurements were performed using a modification of the Ellman procedure (Beutler 1975). Briefly, after centrifugation at $3000 \mathrm{~g}$ for $10 \mathrm{~min}, 0.5 \mathrm{ml}$ supernatant was added to $2 \mathrm{ml} 0.3 \mathrm{~mol} / 1 \mathrm{Na}_{2} \mathrm{HPO}_{4} \cdot 2 \mathrm{H}_{2} \mathrm{O}$ solution. A $0 \cdot 2 \mathrm{ml}$ solution of dithiobisnitrobenzoate $(0 \cdot 4 \mathrm{mg} / \mathrm{ml} 1 \%$ sodium citrate) was added and the absorbance at $412 \mathrm{~nm}$ was measured immediately after mixing. GSH levels were calculated using an extinction coefficient of $1.36 \times$ $10^{5} \mathrm{M} / \mathrm{cm}$. Results are expressed in $\mu \mathrm{mol} \mathrm{GSH} / \mathrm{g}$ tissue.

\section{Measurement of MPO activity}

MPO is an enzyme that is found predominantly in the azurophilic granules of polymorphonuclear leukocytes (PMN). Tissue MPO activity is frequently utilized to estimate tissue PMN accumulation in inflamed tissues and correlates significantly with the number of PMN determined histochemically in tissues (Bradley et al. 1982). MPO activity was measured in tissues in a procedure similar to that documented by Hillegas et al. (1990). Tissue samples were homogenized in $50 \mathrm{mM}$ potassium phosphate buffer (PB; pH 6.0), and centrifuged at $41400 \mathrm{~g}$ (10 min); pellets were suspended in $50 \mathrm{mM}$ PB containing $0 \cdot 5 \%$ hexadecyltrimethylammonium bromide. After three freeze and thaw cycles, with sonication between cycles, the samples were centrifuged at $41400 \mathrm{~g}$ for $10 \mathrm{~min}$. Aliquots $(0.3 \mathrm{ml})$ were added to $2.3 \mathrm{ml}$ reaction mixture containing $50 \mathrm{mM} \mathrm{PB}$, o-dianisidine and $20 \mathrm{mM} \mathrm{H}_{2} \mathrm{O}_{2}$ solution. One unit of enzyme activity was defined as the 

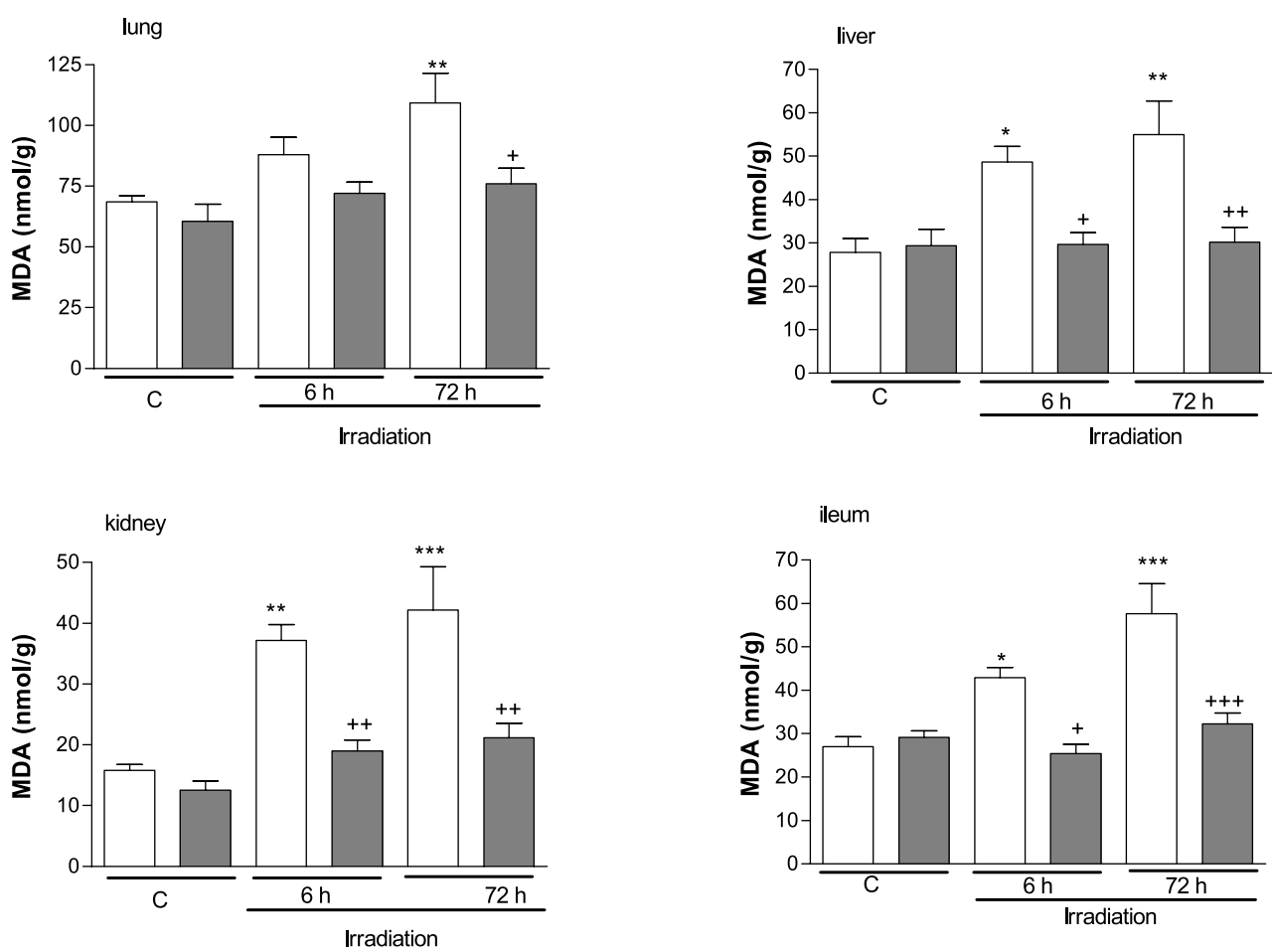

Figure 2 MDA levels in the lung, liver, kidney and ileum tissues of vehicle-treated (open bars) or PTU-treated control groups (shaded bars) decapitated at 6 or $72 \mathrm{~h}$ after irradiation. Each group consists of six rats. ${ }^{*} P<0 \cdot 05,{ }^{*} P<0 \cdot 01,{ }^{* *} P<0 \cdot 001$ compared with control $(\mathrm{C})$ group; ${ }^{+} P<0 \cdot 05,{ }^{++} P<0 \cdot 01$ compared with saline-treated group.

amount of MPO present that caused a change in absorbance measured at $460 \mathrm{~nm}$ for $3 \mathrm{~min}$. MPO activity is expressed as $\mathrm{U} / \mathrm{g}$ tissue.

\section{Tissue collagen measurement}

Tissue collagen was measured as a free radical-induced fibrosis marker. Tissue samples were cut with a razor blade, immediately fixed in $10 \%$ formalin in $0 \cdot 1 \mathrm{M}$ phosphate buffer $(\mathrm{pH} \mathrm{7.2)} \mathrm{in} \mathrm{paraffin,} \mathrm{and} \mathrm{approximately}$ $15 \mu \mathrm{m}$ thick sections were obtained. Evaluation of collagen content was made according to the method published by Lopez de Leon \& Rojkind (1985), based on selective binding of the dyes Sirius Red and Fast Green to collagen and non-collagenous components respectively. Both dyes were eluted readily and simultaneously by using $0 \cdot 1 \mathrm{M}$ $\mathrm{NaOH}-$ methanol $(1: 1, \mathrm{v} / \mathrm{v})$. Finally, the absorbances at 540 and $605 \mathrm{~nm}$ were used to determine the amount of collagen and protein respectively.

\section{CL assay}

To assess the role of ROS in radiation-induced tissue damage, luminol and lucigenin CLs were measured as indicators of radical formation. Measurements were made at room temperature using a Junior LB 9509 luminometer (EG\&G, Berthold, Germany). Specimens were put into vials containing PBS-HEPES buffer ( $0.5 \mathrm{M}$ PBS containing $20 \mathrm{mM}$ HEPES, $\mathrm{pH} 7 \cdot 2$ ). ROS were quantitated after the addition of enhancers such as lucigenin or luminol at a final concentration of $0.2 \mathrm{mM}$. Luminol detects a group of reactive species, i.e. $\mathrm{OH}, \mathrm{H}_{2} \mathrm{O}_{2}, \mathrm{HOCl}$ radicals, and lucigenin is selective for $\mathrm{O}_{2}^{-}$(Ohara et al. 1993, Davies et al. 1994, Haklar et al. 2002). Counts were obtained at 1 -min intervals and the results are given as the area under curve for a counting period of $5 \mathrm{~min}$. The counts were corrected for wet tissue weights and expressed as relative light units (Haklar et al. 2002).

\section{DNA fragmentation assay}

Mucosal samples from ileal tissues were homogenized in 10 volumes of a lysis buffer $(5 \mathrm{mM}$ Tris- $\mathrm{HCl}, 20 \mathrm{mM}$ ethylene diamine tatra-acetic acid (EDTA) and $0 \cdot 5 \%(\mathrm{v} / \mathrm{v})$ $t$-octylphenoxypolyethoxyethanol (Triton-X 100); $\mathrm{pH}$ $8 \cdot 0)$. Two separate samples of $1 \mathrm{ml}$ each were taken from the sample and centrifuged at $25000 \mathrm{~g}$ for $30 \mathrm{~min}$ to separate the intact chromatin in the pellet from the 

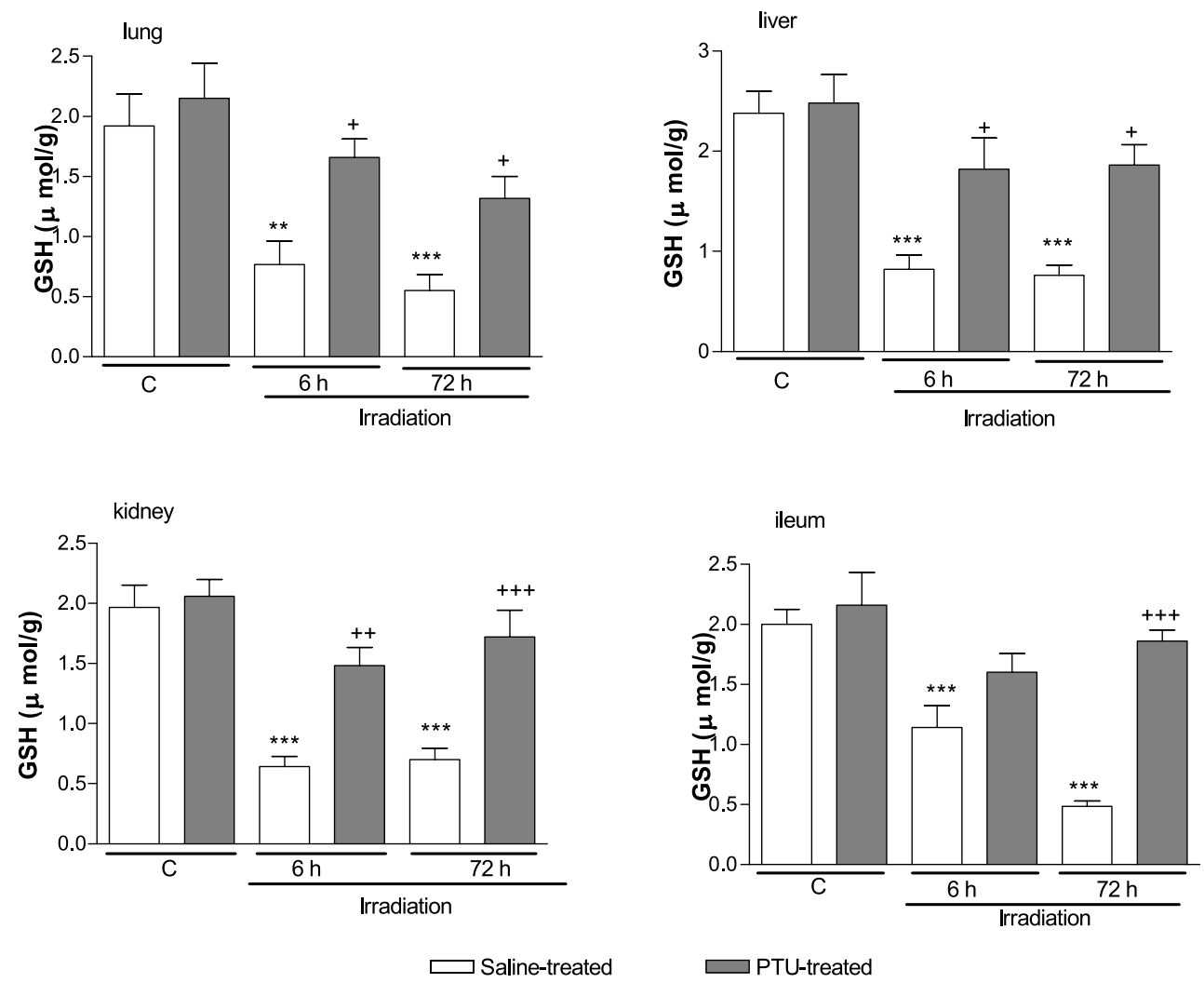

Figure $3 \mathrm{GSH}$ levels in the lung, liver, kidney and ileum tissues of control and vehicle-treated (open bars) or PTU-treated groups (shaded bars) decapitated at 6 or $72 \mathrm{~h}$ after irradiation. Each group consists of six rats. ${ }^{*} P<0 \cdot 05,{ }^{* *} P<0 \cdot 01,{ }^{* *} P<0 \cdot 001$ compared with control (C) group; ${ }^{+} P<0 \cdot 05,{ }^{++} P<0 \cdot 01,{ }^{+++} P<0 \cdot 001$ compared with saline-treated group.

fragmented DNA in the supernatant (Wyllie 1980). The supernatant was taken out to be saved and the pellet was re-suspended in $1 \mathrm{ml}$ Tris-Ethylendiamintetraacetat buffer (pH 8.0) (10 mM:1 mM). Both the supernatant and the re-suspended pellet were then assayed for DNA content determination by the diphenylamine reaction described by Burton (1956).

\section{Histopathological analysis}

Samples of the tissues were fixed in 10\% (v/v) buffered p-formaldehyde and prepared for routine paraffin embedding. Tissue sections $(6 \mu \mathrm{m})$ were stained with haematoxylin and eosin and examined under a light microscope (Olympus-BH-2, Tokyo, Japan) by an experienced histologist who was unaware of the treatment conditions.

\section{Statistics}

Statistical analysis was carried out using GraphPad Prism 4.0 (GraphPad Software, San Diego, CA, USA). All data are expressed as means \pm S.E.M. Groups of data were compared with an ANOVA followed by Tukey's multiple comparison tests. Values of $P<0 \cdot 05$ were regarded as significant.

\section{Results}

In the PTU-treated rats the serum tri-iodothyronine and thyroxine levels $(0 \cdot 21 \pm 0 \cdot 02 \mathrm{ng} / \mathrm{ml}$ and $2 \cdot 2 \pm 0 \cdot 5 \mathrm{ng} / \mathrm{ml})$ were found to be significantly lower than those of the control group $(0.58 \pm 0 \cdot 01 \mathrm{ng} / \mathrm{ml}$ and $29 \cdot 1 \pm 0.6 \mathrm{ng} / \mathrm{ml}$; $P<0 \cdot 001)$.

BUN and creatinine concentrations were studied to assess the renal functions, while serum AST and ALT levels were determined to evaluate the hepatic functions. As shown in Table 1, ALT levels were significantly higher in both irradiated groups decapitated at 6 or 72 after irradiation, when compared with those of the control group $(P<0 \cdot 05-0 \cdot 01)$, while PTU treatment decreased these elevations. AST levels were increased $(P<0 \cdot 05)$ at only $72 \mathrm{~h}$ following irradiation and PTU treatment reversed this alteration back to control levels. However, blood creatinine levels were not changed significantly at 

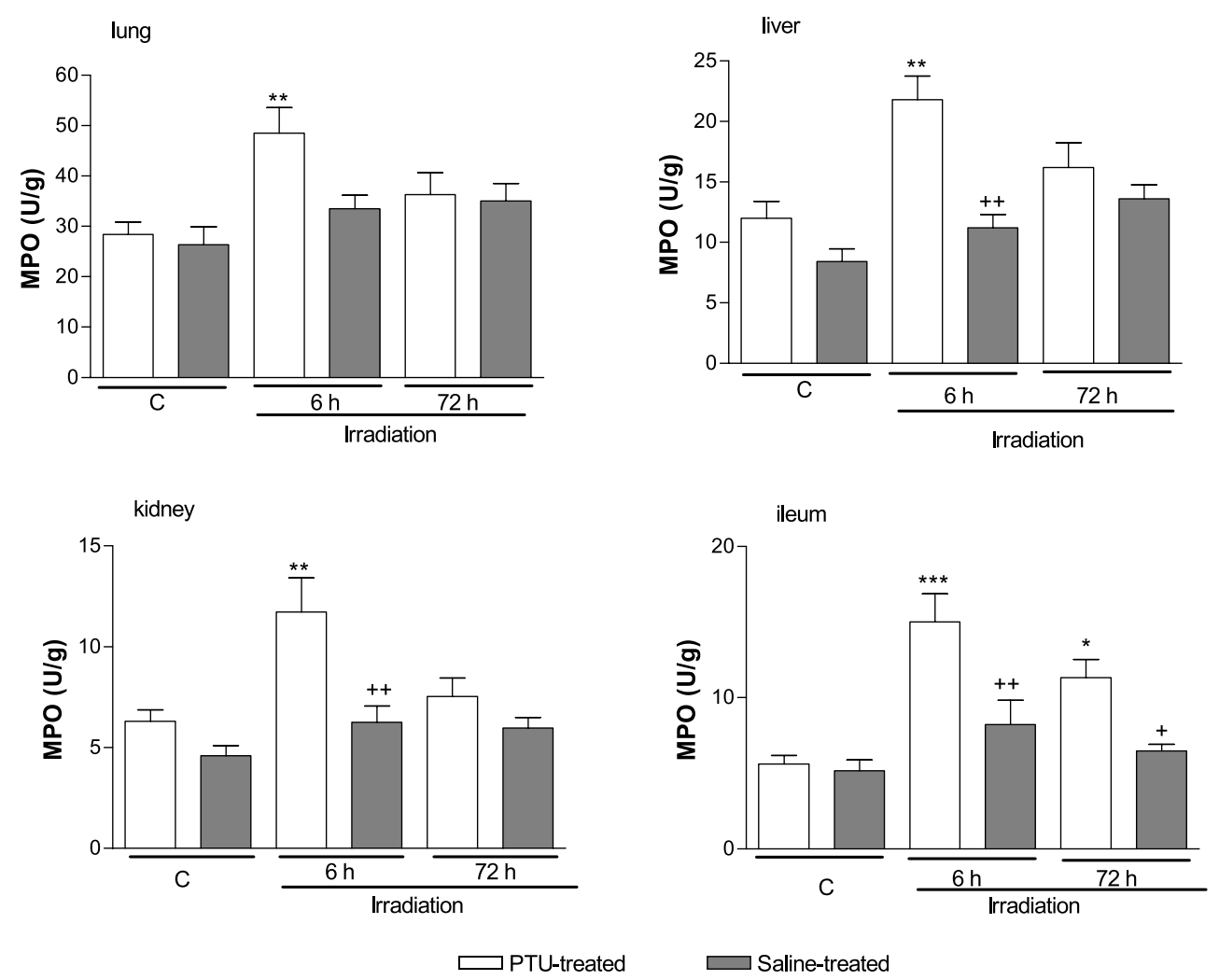

Figure $4 \mathrm{MPO}$ activity in the lung, liver, kidney and ileum tissues of control and vehicle-treated (open bars) or PTU-treated groups (shaded bars) decapitated at 6 or $72 \mathrm{~h}$ after irradiation. Each group consists of six rats. ${ }^{*} P<0 \cdot 05,{ }^{*} P<0 \cdot 01,{ }^{* *} P<0 \cdot 001$ compared with control $(\mathrm{C})$ group; ${ }^{+} P<0 \cdot 05$ compared with saline-treated group.

either 6 or 72 following irradiation (Table 1). Similarly, BUN levels were not different from the control group at $6 \mathrm{~h}$ after irradiation, but they were found to be elevated at $72 \mathrm{~h}$ of irradition $(P<0 \cdot 001)$. On the other hand, this elevation in BUN level was abolished in the PTU-treated irradiated group $(P<0 \cdot 001)$.

In the saline-treated irradiated groups, $\mathrm{TNF} \alpha$ levels were significantly increased $(P<0 \cdot 001)$ when compared with the control group, while this irradiation-induced rise in serum TNF $\alpha$ levels was abolished $(P<0 \cdot 05-0 \cdot 01)$ with PTU treatment (Fig. 1b). Serum LDH activity, as a marker of generalized tissue damage, showed a significant increase in irradiated animals at both time-points $(P<0 \cdot 05-0 \cdot 01)$, while PTU administration reversed this effect $(P<0 \cdot 05-0 \cdot 01$; Fig. 1a).

Luminol and lucigenin CL levels were significantly increased in the lung, liver, kidney and ileum samples of the saline-treated irradiated group as compared with controls $(P<0 \cdot 05-P<0 \cdot 001)$. On the other hand, these values were reversed back to the control levels in all the tissues of PTU-treated irradiated rats $(P<0 \cdot 05-0 \cdot 01)$ (Table 2).

The levels of GSH, the endogenous antioxidant, in the lung, liver, kidney and ileum of saline-treated rats were significantly decreased at 6 and $72 \mathrm{~h}$ following irradiation $(P<0 \cdot 01-0 \cdot 001$; Fig. 2$)$, while treatment with PTU led to replenishment of the tissue GSH contents $(P<0 \cdot 05-$ 0.001). Except for the lipid peroxidation of the lung tissue, which showed a tendency to increase at $6 \mathrm{~h}$ of irradiation without reaching statistical significance, MDA levels were significantly higher in both irradiation groups (Fig. 3) as compared with the control group $(P<0 \cdot 05-0 \cdot 001)$. However, treatment with PTU significantly $(P<0 \cdot 05-0 \cdot 001)$ reversed irradiation-induced elevations in MDA levels back to the control levels in all the tissues.

At $6 \mathrm{~h}$ of irradiation, significant increases in the MPO activity of the lung, liver, kidney and ileal tissues were observed, indicating tissue neutrophil infiltration (Fig. 4). Except for the ileum, this early neutrophil accumulation was not any more evident at $72 \mathrm{~h}$ of irradiation. On the other hand, PTU treatment abolished irradiation-induced increases in MPO activity at the early period of irradiation in all the tissues $(P<0 \cdot 01)$, while sustained elevation in MPO activity of the ileum was also suppressed by PTU treatment.

As an indicator of enhanced tissue fibrotic activity, collagen contents of the studied tissues were markedly 

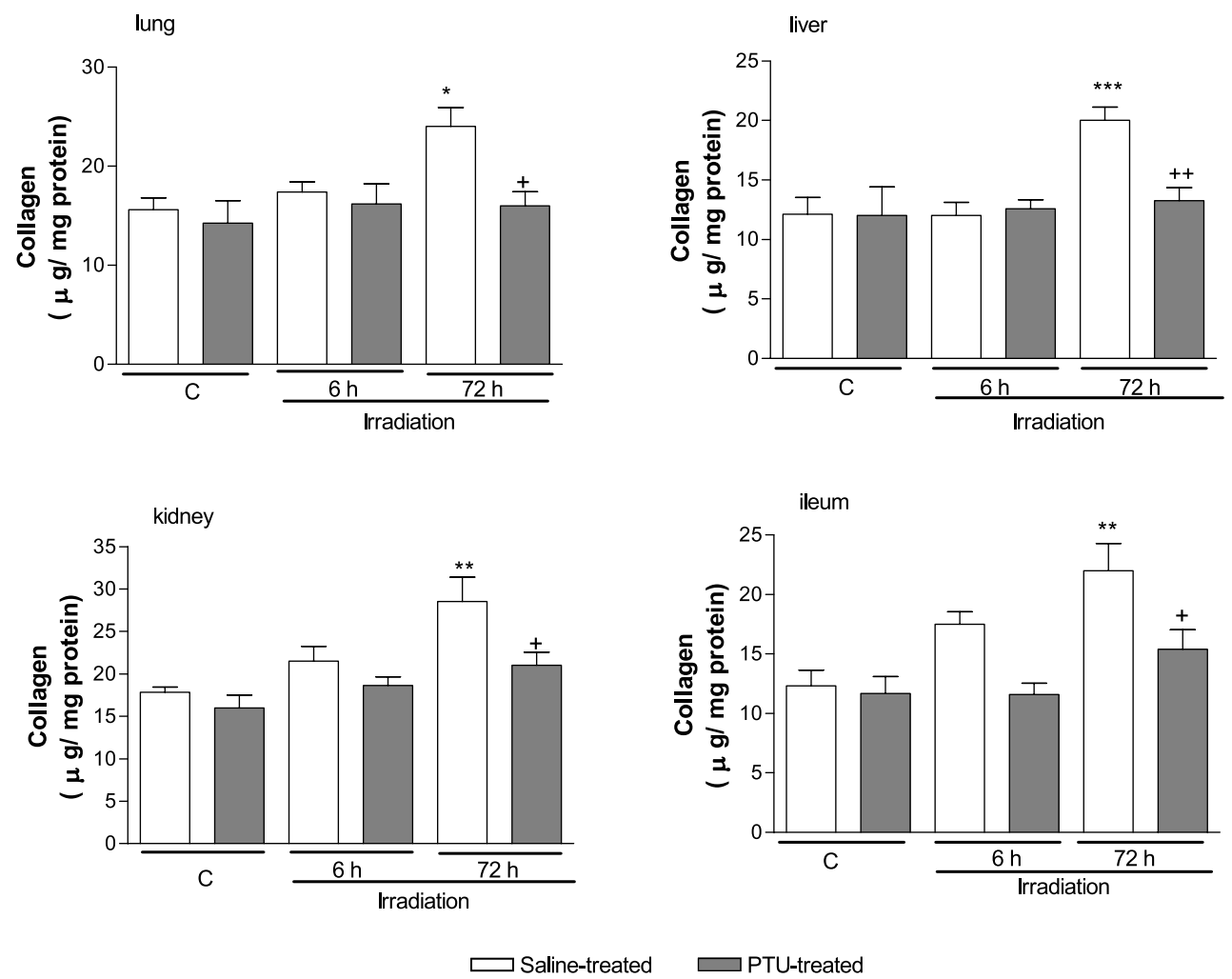

Figure 5 Collagen contents in the lung, liver, kidney and ileum tissues of control and vehicle- treated (open bars) or PTU-treated groups (shaded bars) decapitated at 6 or $72 \mathrm{~h}$ after irradiation. Each group consists of six rats. ${ }^{*} P<0 \cdot 05,{ }^{* *} P<0 \cdot 01,{ }^{* * *} P<0 \cdot 001$ compared with control (C) group; ${ }^{+} P<0 \cdot 05,{ }^{++} P<0 \cdot 01$ compared with saline-treated group.

increased at $72 \mathrm{~h}$ of irradiation in saline-treated groups when compared with the control group $(P<0 \cdot 05-0 \cdot 001$;

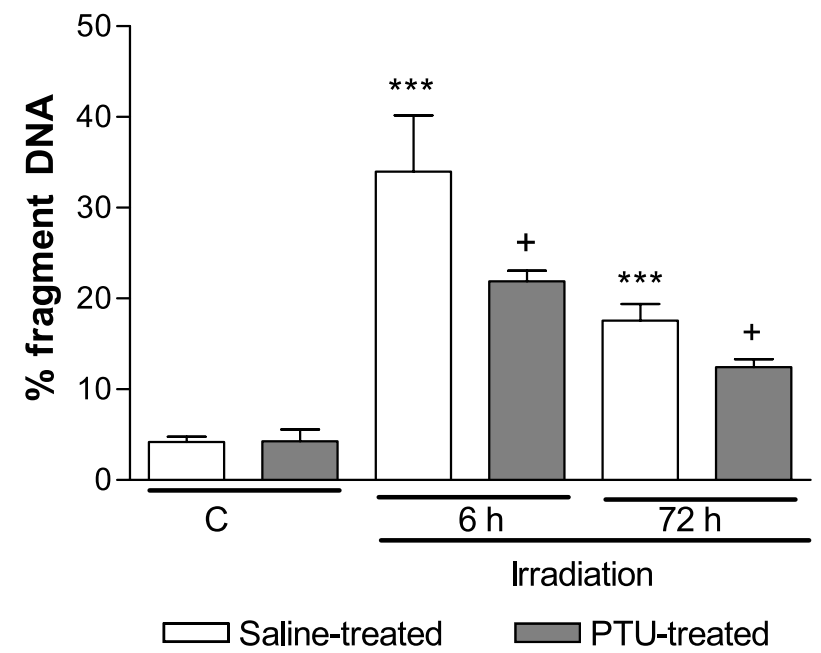

Figure 6 DNA fragmentation (\%) in the ileal mucosa of control (C) and vehicle-treated (open bars) or PTU-treated groups (shaded bars) decapitated at 6 or $72 \mathrm{~h}$ after irradiation. Each group consists of six rats.
Fig. 5); but no changes in collagen contents were observed at the earlier post-irradiation period. On the other hand, PTU-induced hypothyroidism prevented the increases in collagen levels, returning these levels back to control levels $(P<0 \cdot 05-0 \cdot 01)$.

Since the intestinal mucosa has a rapid turnover of cellular regeneration, cDNA fragmentation (\%) in the ileal mucosa was analyzed as an indicator of apoptosis.

DNA fragmentation was elevated in the ileal mucosae of saline-treated groups at both early and later postirradiation periods $(P<0 \cdot 001)$, while PTU treatment significantly prevented the DNA damage $(P<0 \cdot 05)$ (Fig. 6).

In histopathological analysis, slight degenerations were observed in all tissues when examined at $6 \mathrm{~h}$ following irradiation, while the effect of irradiation was more degenerative for the tissues at $72 \mathrm{~h}$. PTU treatment exerted very clear ameliorating effects on all tissues especially in the $72-h$ group. Dilations of sinusoids, prominent congestion in both sinusoids and central veins, parenchymal detachment of the linear hepatocyte cords and cellular degeneration were the observed features of the saline-treated irradiation groups specifically at $72 \mathrm{~h}$ (Fig. 7A and C). PTU treatment led to the reversal of degenerations in both irradiated groups where the 

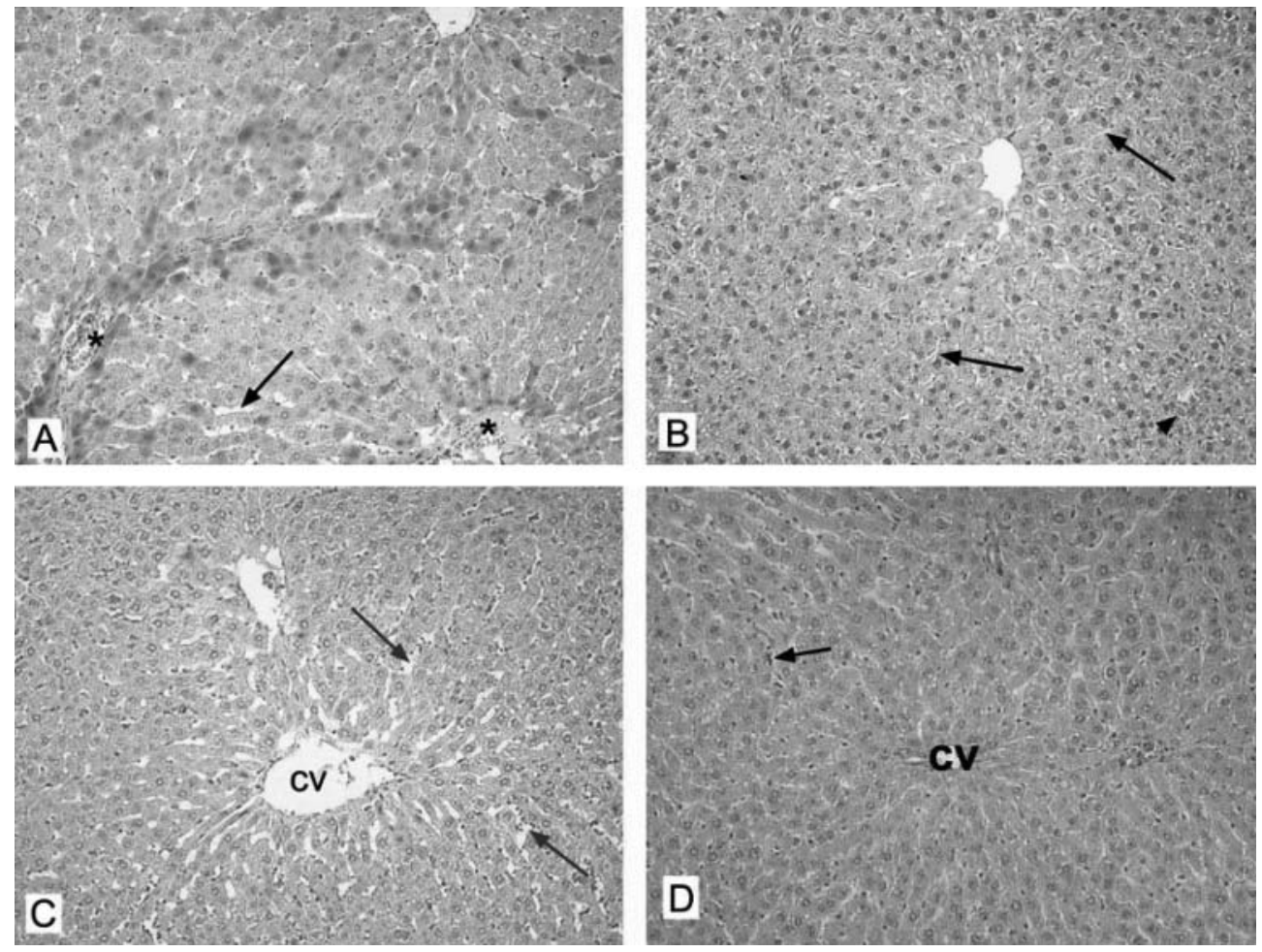

Figure 7 Micrographs of the (A) saline-treated group decapitated at $6 \mathrm{~h}$ following irradiation: dilations in the sinusoids (arrow); also note the congestion in the central veins $\left(^{*}\right)$, (B) PTU-treated group decapitated at $6 \mathrm{~h}$ following irradiation: reduced sinusoidal dilation (arrows) and some degenerative hepatocytes (arrowhead), (C) saline-treated group decapitated at $72 \mathrm{~h}$ following irradiation: aberrant sinusoidal dilations (arrows) besides detachment of the liver parenchyme and hepatocyte degeneration and (D) PTU-treated group decapitated at $72 \mathrm{~h}$ following irradiation: note the integrity of liver parenchyme with some persistant congestion of sinusoids (arrow) and portal triad with central vein (cv). (Haematoxylin and eosin; $\times 200$.)

structure of sinusoids was re-established and congestion of the sinusoids was reduced (Fig. 7B and D).

At $6 \mathrm{~h}$ of irradiation, mild interstitial congestion, reduction of the alveolar area and oedema were observed in the parenchyme that were reversed with PTU treatment (Fig. 8A and B). In lung tissues, severe interstitial oedema with bronchiolar haemorrhage observed in the irradiated group at $72 \mathrm{~h}$ was ameliorated by PTU treatment, revealing the reversal of degeneration and interstitial oedema compared with the saline-treated group (Fig. 8C and D).

In the saline-treated irradiated groups, mild tubular and glomerular degenerations with congestion in the glomeruli and peritubular dilations were replaced by extensive kidney damage with tubular epithelial desquamation leading to cellular debris in the tubuli and severe atrophy (Fig. 9A and C). PTU-treated irradiated groups showed better organized tubular and glomerular structures with well-established epithelia which resembled that of the control group (Fig. 9B and D).

In the groups decapitated at $6 \mathrm{~h}$ following irradiation, mild villous detachments of the ileum were observed in the saline-treated group while, in the PTU-treated group, a regular villi structure was observed (Fig. 10A and B). These findings were in accordance with those found in the intestines, where severe epithelial loss of the villi and inflammatory cell invasion in the lamina propria of the group treated for $72 \mathrm{~h}$ were replaced by regular tissue integrity and many goblet cells in the epithelium of the PTU-treated group (Fig. 10C and D).

\section{Discussion}

The results of the current study have demonstrated that irradiation-induced oxidative damage of the lung, liver, kidney and ileum tissues is ameliorated by PTU-induced hypothyroidism. Oxidative injury, evidenced by the elevated MDA levels, MPO activity, collagen content, and depleted GSH levels, as well as morphological changes and impairments in hepatic and renal functions due to irradiation were improved by PTU treatment. These findings suggest that PTU-induced hypothyroidism, by inhibiting oxygen metabolite production, neutrophil infiltration and subsequent activation of inflammatory 

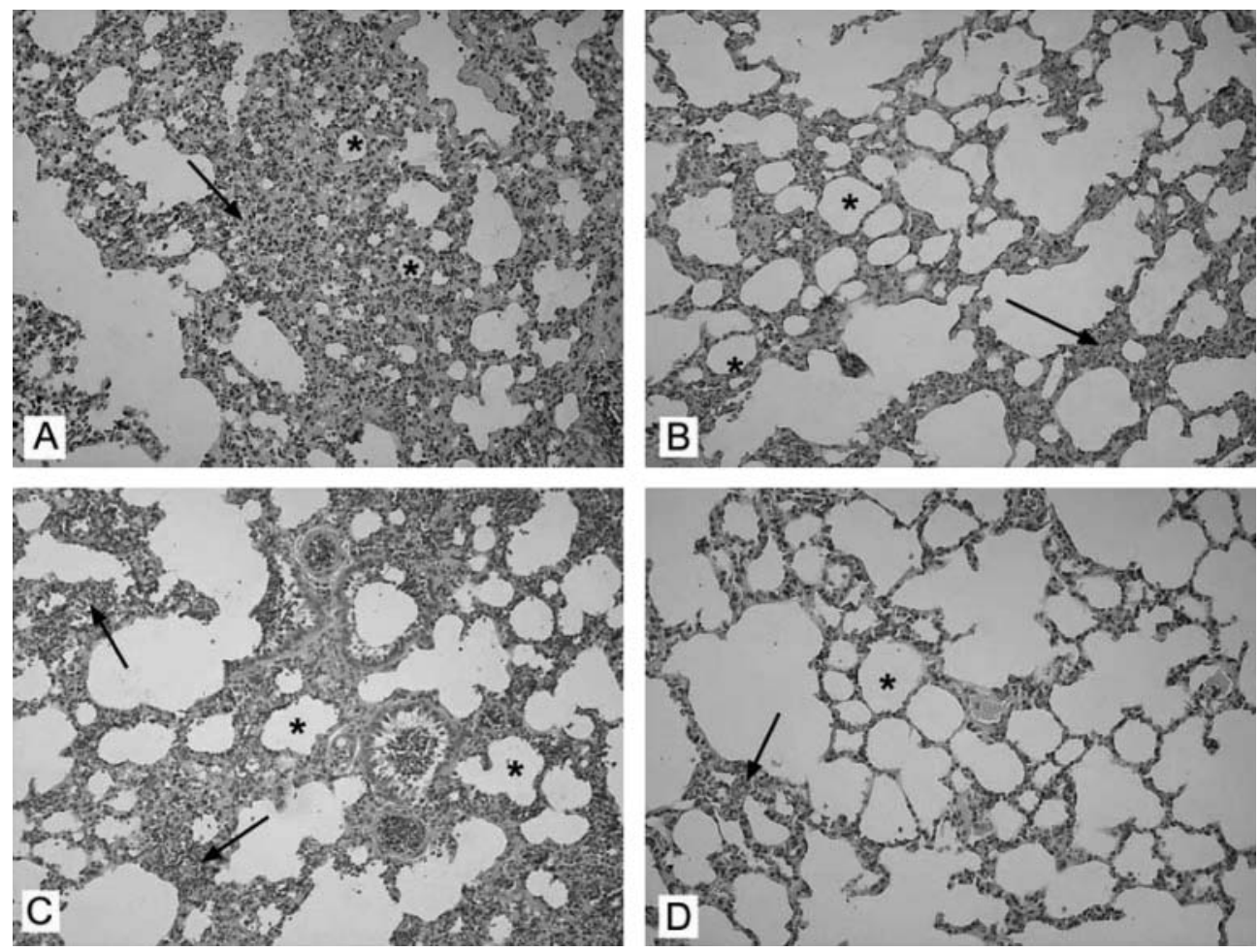

Figure 8 Micrographs of lung tissue in (A) the saline-treated group decapitated at $6 \mathrm{~h}$ following irradiation: moderate interstitial congestion and oedema in the lung parenchyme (arrow): note the reduced alveolar areas $\left({ }^{*}\right),(B)$ PTU-treated group decapitated at $6 \mathrm{~h}$ following irradiation: reduced interstitial congestion and oedema (arrow) and expanded alveolar areas $\left(^{*}\right),(\mathrm{C})$ saline-treated group decapitated at $72 \mathrm{~h}$ following irradiation: severe oedema and interstitial congestion (arrows) with reduced alveolar areas (*); note the haemorrhage in the bronchiole and (D) PTU-treated group decapitated at $72 \mathrm{~h}$ following irradiation: clearly reduced interstitial oedema and haemorrhage (arrow) and re-established alveolar structure $\left(^{*}\right)$.

(Haematoxylin and eosin; $\times 200$.)

mediators that induce lipid peroxidation, appears to have a protective role in the irradiation-induced oxidative damage.

In addition to its inhibitory effects on thyroid hormone synthesis, PTU has potential immunomodulatory (Wilson et al. 1988) and antioxidant effects (Hicks et al. 1992). Accordingly, PTU has been shown to act as a highly efficient scavenger of $\mathrm{OH}$ radicals, to be a potent inhibitor of lipid peroxidation in model membranes (Hicks et al. 1992) and to inhibit $\mathrm{H}_{2} \mathrm{O}_{2}$ production in neutrophils (Imamura et al. 1986) or Graves' retro-ocular fibroblasts (Heufelder et al. 1992). It has also been observed that hyperthyroid patients treated with PTU have decreased serum MDA levels, suggesting that PTU may scavenge ROMs or may directly protect lipids from peroxidative attack (Videla et al. 1988). In accordance with these results, in the present study tissue MDA was increased in the lung, liver, kidney and ileum of whole-body irradiated rats, indicating the presence of radiation-induced oxidative damage. Peroxidation of membrane lipids can disrupt membrane fluidity and cell compartmentation, which may contribute to impaired cellular function and necrosis (Reiter et al. 2001). The present findings have shown that irradiation impaired the renal and hepatic functions, while PTU treatment prevented elevations in tissue MDA and attenuated the impairments in the liver and kidney functions. Furthermore, luminol- and lucigenin-enhanced CL levels were reduced in PTU-treated rats, implicating that amelioration of radiation-induced oxidative injury by PTU involves reduction in oxygen metabolism and scavenging of reactive oxygen radicals. Although it is difficult to quantitate oxygen radicals because of their reactive nature and short lives, luminol- and lucigeninenhanced CL is a simple and reproducible tool indicating the involvement of free radicals. Despite the selectivity of the probes used in the study (Ohara et al. 1993, Davies et al. 1994, Haklar et al. 2002), our CL data support the notion that tissue injury induced by irradiation involves toxic oxygen metabolites without any selectivity.

GSH, a well-known antioxidant, provides major protection in oxidative injury by participating in the cellular system of defence against oxidative damage (Ross 1988). 

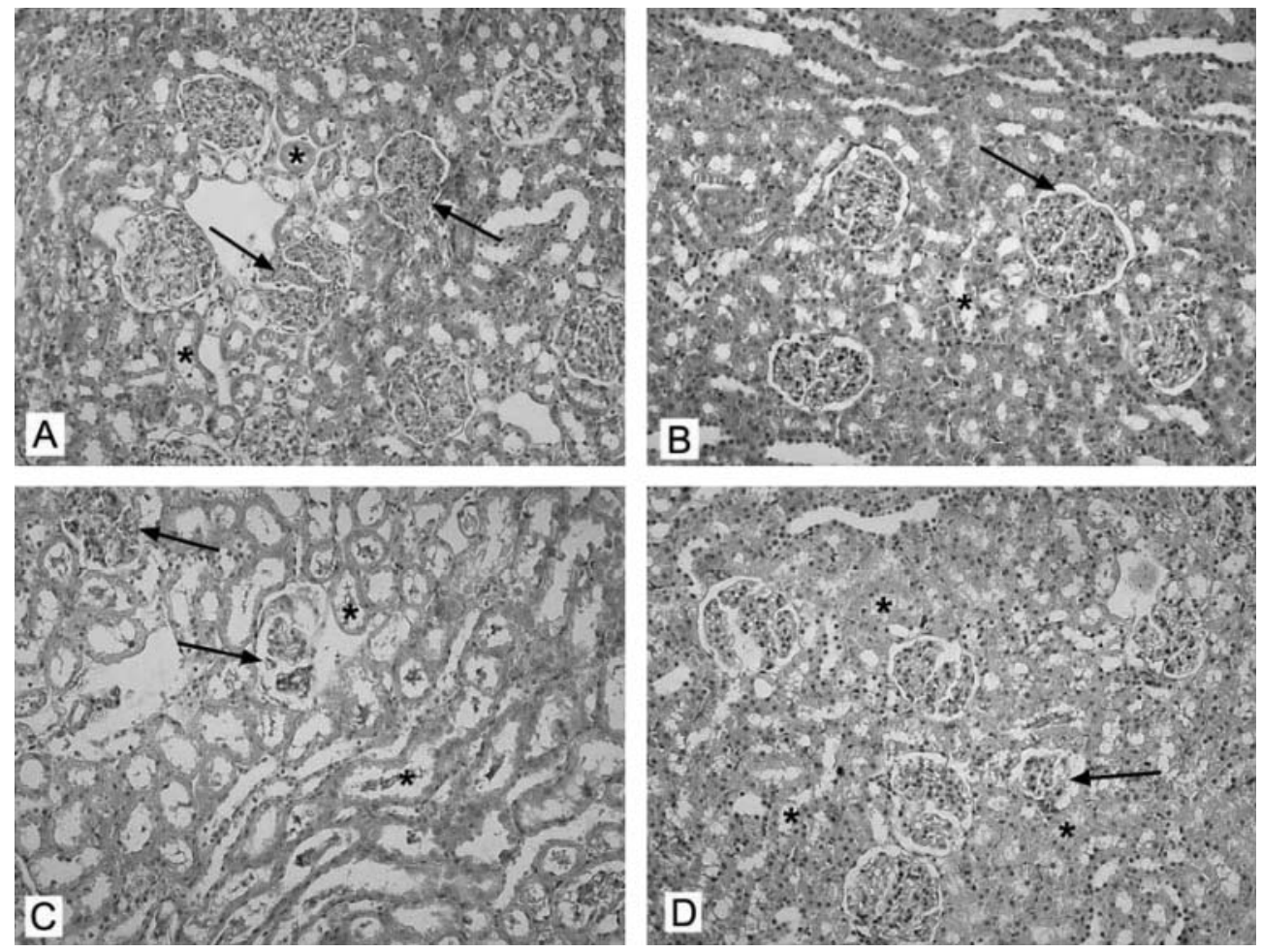

Figure 9 Micrographs of renal tissue in (A) saline-treated group decapitated at $6 \mathrm{~h}$ following irradiation: moderate tubular damage $\left(^{*}\right)$ and slight glomerular deterioration (arrows), (B) PTU-treated group decapitated at $6 \mathrm{~h}$ following irradiation: tubuli restored to normal $\left(^{*}\right)$ whereas some glomeruli seem regular (arrow) but some persist as slightly damaged, (C) saline-treated group decapitated at $72 \mathrm{~h}$ following irradiation: severe glomerular atrophy (arrows) and invasive tubular damage $\left({ }^{*}\right)$ with epithelial loss leading to cellular debris in the tubules and (D) PTU-treated group decapitated at $72 \mathrm{~h}$ following irradiation: overall structure seems to be regular tissue with nearly normal glomeruli (arrow) and tubuli $\left({ }^{*}\right)$ while a slightly degenerated glomerulus persists. (Haematoxylin and eosin; $\times 200$.)

It was reported that tissue GSH levels and the activities of GSH reductase and GSH peroxidase, which are critical constituents of the GSH-redox cycle, were significantly reduced due to oxidative stress, permitting enhanced free radical-induced tissue damage (Reiter et al. 2001). In the present study, the decrease in tissue GSH levels may be due to its consumption during the oxidative stress induced by irradiation. On the other hand, treatment with PTU prevented GSH depletion by decreasing free radical generation. There is a good deal of evidence to indicate that metabolic depression brought about by hypothyroidism is associated with a decrease in free radical production and subsequent protection against oxidative damage (Asayama et al. 1987). In contrary, high concentrations of thyroid hormones were shown to increase the metabolism of oxygen in aerobic conditions and stimulate free radical generation (Fernandez \& Videla 1989). Thus, reduced demand for oxygen and concomitant suppression of free radical formation in hypothyroidism appears to serve as a protective factor in radiation-induced oxidative injury.
Tissue macrophages and monocytes respond to any noxious event by secreting cytokines such as interleukin-1 and TNFa (Schwacha 2003, Enomoto et al. 2004). As evidenced in the present study, irradiation resulted in increased serum $\mathrm{TNF} \alpha$, indicating the role of this cytokine in irradiation-induced toxicity, while depression of the TNF $\alpha$ response by PTU implicates the inhibitory effect of PTU on the release of this pro-inflammatory cytokine. In our observations, elevated MPO levels in the tissues indicate that neutrophil accumulation contributes to the irradiation-induced oxidative injury and PTU appears to have a preventive effect through the inhibition of neutrophil infiltration and subsequent release of proinflammatory mediators. Observations suggest that ROMs play a role in the recruitment of neutrophils into injured tissues, but activated neutrophils are also a potential source of ROMs (Kettle \& Winterbourn 1997). Thus, it seems likely that the alleviation of irradiation-induced oxidative tissue damage by PTU involves the suppression of a variety of pro-inflammatory mediators produced by leukocytes and macrophages. It is known that PTU inhibits not 

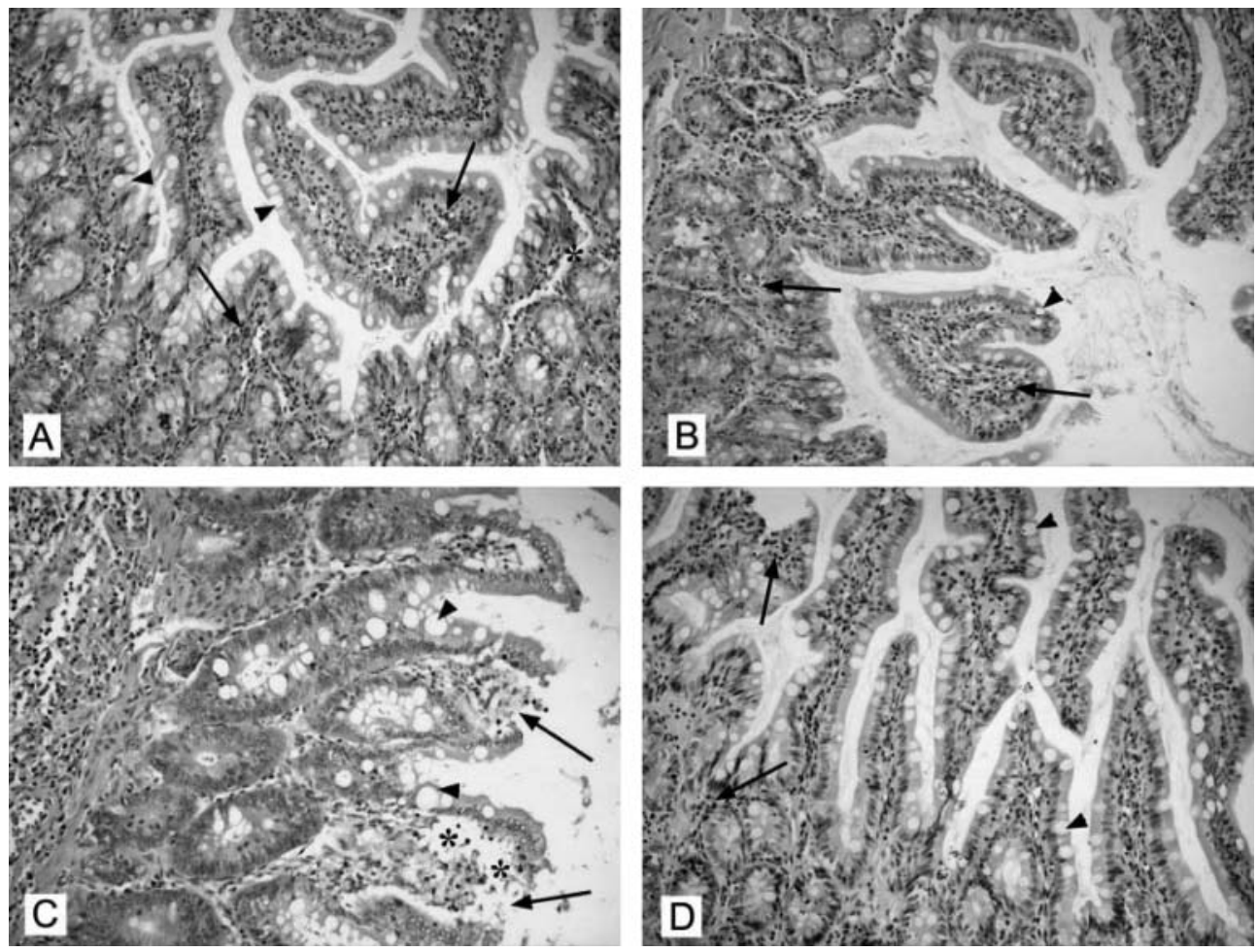

Figure 10 Micrograph of the intestines. (A) Saline-treated group decapitated at $6 \mathrm{~h}$ following irradiation: the epithelium is not distorted but the number and the distension of goblet cells with mucus increased (arrowheads) and the amount of inflammatory cells in lamina propria is high (arrows): note the oedema in the lamina propria $\left(^{*}\right),(B)$ PTU-treated group decapitated at $6 \mathrm{~h}$ following irradiation: there is a mild decrease in the number and the distension of the goblet cells (arrowhead) and there are still inflammatory cells (arrows) present but not as many as in the previous group, (C) saline-treated group decapitated at $72 \mathrm{~h}$ following irradiation: prominent desquamation of the epithelium (arrows) with severe oedema $\left(^{*}\right)$ in the lamina propria: note the distended goblet cells (arrowheads) and (D) PTU-treated group decapitated at $72 \mathrm{~h}$ following irradiation: the epithelium gained its integrity with reduced oedema, the density of the inflammatory cells decreased (arrows) and the distension of the goblet cells (arrowheads) is still present. (Haematoxylin and eosin; $\times 200$.)

only the catalytic activity of thyroid peroxidase, but also the other members of the mammalian peroxidases, such as MPO, lactoperoxidase, eosinophil peroxidase and salivary peroxidase (Taurog 1999). Although it was shown that PTU is a direct inhibitor of MPO function (Taurog \& Dorris 1992), our data related to the effect of PTU on non-irradiated rats demonstrated that MPO activity was not different from the non-treated control rats. It appears that PTU does not have a significant impact on basal MPO activity, but it may have a direct inhibitory effect on inflammation-induced enhanced MPO activity. Thus, the protective effects of PTU on radiation-induced injury is not solely related to its anti-thyroidal action which reduces the oxidative metabolism but it may also involve the direct inhibitory effect of PTU on MPO activity.

In vital organs (such as the heart, kidney, lung or liver) tissue injury caused by a range of insults, including oxidative stress, can result in the development of progressive fibrosis leading to ultimate organ failure
(Franklin 1997, Martin et al. 2000). The risk of irradiation-induced fibrosis, occurring in normal tissues several months to years after radiotherapy, remains a major factor in limiting the radiation dose that can be applied safely to cancer patients. In the current study, collagen contents of the studied tissues were significantly increased at $72 \mathrm{~h}$ following irradiation, indicating the presence of tissue fibrotic activity, while PTU treatment attenuated the fibrotic activity by its antioxidant properties. It has been shown that irradiation dramatically increases the low level of spontaneous apoptosis in intestinal crypts (Potten et al. 1994, Potten 1997), which normally occurs to protect against the survival and expansion of genetically damaged cells. Our results indicated that whole-body irradiation increased the apoptotic ratio of ileal epithelium, which seems to be responsible for severe epithelial loss of the villi. On the other hand, PTU treatment suppressed the high percentage of DNA 
fragmentation, while epithelial integrity was maintained. Although it was shown that PTU inhibits cell proliferation and migration by a phosphatidylinositol 3-kinase-mediated pathway (Chen et al. 2004), there is no direct evidence to support the idea that PTU has an impact on malignant cell proliferation. Since radiotherapy cannot be precisely targeted to facilitate the apoptosis of tumour cells without affecting the healthy cells, and the apoptosis of the normal tissue cells is inevitable, further studies are required to evaluate the anti-proliferative and protective effects of PTU on malignant and non-malignant cells respectively.

The current data have suggested that PTU reverses oxidant responses to irradiation and thereby reduces inflammation and subsequent organ failure by depressing neutrophil infiltration and the associated release of proinflammatory cytokines. In conclusion, PTU merits consideration as an antioxidant and anti-inflammatory agent in ameliorating the severity of irradiation-induced multiple organ injury.

\section{Acknowledgements}

The authors are grateful to Dr M Şengöz and Z Özen for their support in conducting the irradiation procedure. The authors declare that there is no conflict of interest that would prejudice the impartiality of this scientific work.

\section{References}

Agrawal A, Chandra D \& Kale RK 2001 Radiation induced oxidative stress: II studies in liver as a distant organ of tumor bearing mice. Molecular and Cellular Biochemistry 224 9-17.

Asayama K \& Kato T 1990 Oxidative muscular injury and its relevance to hyperthyroidism. Free Radical Biology and Medicine 8 293-303.

Asayama K, Dobashi K, Hayashibe H, Megata Y \& Kat K 1987 Lipid peroxidation and free radical scavengers in thyroid dysfunction in the rat: a possible mechanism of injury to heart and skeletal muscle in hyperthyroidism. Endocrinology 121 2112-2118.

Beuge JA \& Aust SD 1978 Microsomal lipid peroxidation. Methods in Enzymology 52 302-311.

Beutler E 1975 Glutathione in red blood cell metabolism. In $A$ Manual of Biochemical Methods, pp 112-114. Ed E Beutler. New York, NY, USA: Grune \& Stratton.

Bradley PP, Priebat DA, Christersen RD \& Rothstein G 1982 Measurement of cutaneous inflammation. Estimation of neutrophil content with an enzyme marker. Journal of Investigative Dermatology 78 206-209.

Brzezinska-Slebodzinska E 2001 Fever induced oxidative stress: the effect on thyroid status and the $5^{\prime}$-monodeiodinase activity, protective role of selenium and vitamin E. Journal of Physiology and Pharmacology 52 275-284.

Burton K 1956 A study of the conditions and mechanism of the diphenylamine reaction for the colorimetric estimation of deoxyribonucleic acid. Biochemical Journal 62 315-323.

Chen WJ, Lin KH, Lai YJ, Yang SH \& Pang JH 2004 Protective effect of propylthiouracil independent of its hypothyroid effect on atherogenesis in cholesterol-fed rabbits: PTEN induction and inhibition of vascular smooth muscle cell proliferation and migration. Circulation 110 1313-1319.
Daly JM, Bertagnoli M, De Cosse JJ \& Morton DL 1999 Oncology. In Principles of Surgery, vol. 1, pp 335-345. Ed SI Schwartz. New York, NY, USA: McGraw-Hill.

Davies GR, Simmonds NJ, Stevens TR, Sheaff MT, Banatvala N, Laurenson I F, Blake DR \& Rampton DS 1994 Helicobacter pylori stimulates antral mucosal reactive oxygen metabolite production in vivo. Gut 35 179-185.

Edwards JC, Chapman D, Cramp WA \& Yatvin MB 1984 The effects of ionizing radiation on biomembrane structure and function. Progress in Biophysics and Molecular Biology 43 71-93.

Enomoto N, Takei Y, Yamashina S, Fukuda T, Suzuki S, Ikejima K, Kitamura T \& Sato N 2004 Burn injury sensitizes rat Kupffer cells via mechanisms dependent on gut-derived endotoxin. Journal of Gastroenterology 39 1175-1181.

Fernandez V \& Videla LA 1989 Thyroide hormone, active oxygen and lipid peroxidation. In Handbook of Free Radicals and Antioxidants in Biomedicine, pp 105-115. Eds J Miquel, AT Ouintanilha \& H Weber. Boca Raton, FL, USA: CRC Press Inc.

Franklin TJ 1997 Therapeutic approaches to organ fibrosis. International Journal of Biochemistry and Cell Biology 29 79-89.

Guerrero A, Pamplona R, Portero-Otin M, Barja G \& Lopez-Torres M 1999 Effect of thyroid status on lipid composition and peroxidation in the mouse liver. Free Radical Biology and Medicine 26 73-80.

Haklar U, Yüksel M, Velioğlu A, Türkmen M, Haklar G \& Yalçın AS 2002 Oxygen radicals and nitric oxide levels in chondral or meniscal lesions or both. Clinical Orthopaedics and Related Research 403 135-142.

Heufelder AE, Wenzel BE \& Bahn RS 1992 Methimazole and propylthiouracil inhibit the oxygen free radical-induced expression of a 72 kilodalton heat shock protein in Graves' retroocular fibroblasts. Journal of Clinical Endocrinology and Metabolism $74737-742$.

Hicks M, Wong LS \& Day RO 1992 Antioxidant activity of propylthiouracil. Biochemical Pharmacology 43 439-444.

Hillegas LM, Griswold DE, Brickson B \& Albrightson-Winslow C 1990 Assesment of myeloperoxidase activity in whole rat kidney. Journal of Pharmacological Methods 24 285-295.

Imamura M, Aoki N, Saito T, Ohno Y, Maruyama Y, Yamaguchi J \& Yamamoto T 1986 Inhibitory effects of antithyroid drugs on oxygen radical formation in human neutrophils. Acta Endocrinologica 112 210-216.

Karbownik M \& Lewinski A 2003 The role of oxidative stress in physiological and pathological processes in the thyroid gland; possible involvement in pineal-thyroid interactions. Neuroendocrinology Letters 24 293-303.

Kettle AJ \& Winterbourn CC 1997 Myeloperoxidase: a key regulator of neutrophil oxidant production. Redox Report 3 3-15.

Lopez de Leon A \& Rojkind M 1985 A simple micromethod for collagen and total protein determination in formalin-fixed parraffin-embedded sections. Journal of Histochemistry and Cytochemistry 33 737-743.

Martin M, Lefaix J-L \& Delanian S 2000 TGF- $\beta 1$ and radiation fibrosis: a master switch and a specific therapeutic target? International Journal of Radiation Oncology-Biology-Physics 47 277-290.

Martinek RG 1972 A rapid ultraviolent spectrophotometric lactic dehydrogenase assay. Clinica Chimica Acta 40 91-99.

Moss DW, Henderson AR \& Kachmar JF 1987 Enzymes. In Fundamentals of Clinical Chemistry, pp 372-373. Ed NW Tietz. Philadelphia, PA, USA: WB Saunders Company.

Ohara Y, Peterson TE \& Harrisorn DG 1993 Hypercholesterolemia increases endothelial superoxide anion production. Journal of Clinical Investigation 92 2546-2551.

Paller MS 1986 Hypothyroidism protects against free radical damage in ischemic acute renal failure. Kidney International 29 1162-1166. 
Potten CS 1997 Epithelial cell growth and differentiation. II. Intestinal apoptosis. American Journal of Physiology 273 G253-G257.

Potten CS, Merritt A, Hickman J, Hall P \& Faranda A 1994 Characterization of radiation-induced apoptosis in the small intestine and its biological implications. International Journal of Radiation Biology 65 71-78.

Reiter RJ, Tan DX, Manchester LC \& Qi W 2001 Biochemical reactivity of melatonin with reactive oxygen and nitrogen species. A review of the evidence. Cell Biochemistry and Biophysics $34237-256$.

Robbins ME \& Zhao W 2004 Chronic oxidative stress and radiation-induced late normal tissue injury: a review. International Journal of Radiation Biology 80 251-259.

Roodyn DB, Freeman KB \& Tata JR 1965 The stimulation by treatment in vivo with tri-iodothyronine or amino acid incorporation into protein by isolated rat liver mitochondria. Biochemical Journal 94 628-641.

Ross D 1988 Glutathione, free radicals and chemotherapeutic agents. Pharmacology and Therapeutics 37 231-249.

Schwacha MG 2003 Macrophages and post-burn immune dysfuction. Burns 29 1-14.

Slot C 1965 Plasma creatinine determination. A new and specific Jaffe reaction method. Scandinavian Journal of Clinical Laboratory Investigation 17 381-387.

Swaroop A \& Ramasarma T 1985 Heat exposure and hypothyroid conditions decrease hydrogen peroxide generation in liver mitochondria. Biochemical Journal 226 403-408.
Talke H \& Schubert GE 1965 Enzymatic urea determination in the blood and serum in the Warburg optical test. Klinische Wochenschrift 43 174-175.

Taurog A 1999 Molecular evolution of thyroid peroxidase. Biochimie 81 557-562.

Taurog A \& Dorris ML 1992 Myeloperoxidase-catalyzed iodination and coupling. Archives of Biochemistry and Biophysics 296 239-246.

Venditti P, Balestrieri M, Di Meo S \& De Leo T 1997 Effect of thyroid state on lipid peroxidation, antioxidant defences, and susceptibility to oxidative stress in rat tissues. Journal of Endocrinology 155 151-157.

Videla LA, Sir T \& Wolff C 1988 Increased lipid peroxidation in hyperthyroid patients: suppression by propylthiouracil treatment. Free Radical Research and Communication 5 1-10.

Wilson R, McKillop JH, Chopra M \& Thomson JA 1988 The effect of antithyroid drugs on $\mathrm{B}$ and $\mathrm{T}$ cell activity in vitro. Clinical Endocrinology 28 389-397.

Wyllie H 1980 Glucocorticoid induced thymocyte apoptosis is associated with endogenous endonuclease activation. Nature $284555-556$.

Received in final form 6 December 2005

Accepted 18 January 2006

Made available online as an

Accepted Preprint 1 February 2006 